\title{
Pengaruh Penggunaan Multimedia Interaktif dan Gaya Belajar Terhadap Hasil Belajar Bahasa Inggris
}

\author{
Suryanto*, Muhajir, Kusmiyati \\ Magister Teknologi Pendidikan, Universitas Dr. Soetomo \\ *Corresponding Author. Email: suryanto@gmail.com
}

\begin{abstract}
This study aims to analyze the effect of using interactive multimedia and learning styles on students' English learning outcomes. The research approach is a quantitative approach with a quasi-experimental research type. The subject of this research is class XI private high school in Driyorejo - Gresik sub-district in the odd semester of the 2019/2020 academic year. The sample was taken using purposive cluster sampling by considering the characteristics of the school and obtained two schools, namely SMA Raden Fatah as the control group and SMA AL-Furqon as the experimental group. The number of SMA Raden Fatah students is 36 students while SMA AL-Furqon is 39 students. In the learning process, the control group used powerpoint presentation media and the experimental group used flash-based interactive multimedia learning. The research data were collected through a learning style identification test and a student learning outcome test. Data were analyzed with the help of the SPSS 24 for windows program, with a two-way ANOVA test at a significance level of 0.05 . The results of this study are that there is an effect of the use of interactive multimedia learning between groups of students with visual, auditory and kinesthetic learning styles together on students' English learning outcomes.
\end{abstract}

Abstrak: Penelitian ini bertujuan untuk menganalisis pengaruh penggunaan multimedia interaktif dan gaya belajar terhadap hasil belajar bahasa inggris siswa. Pendekatan penelitian ini adalah pendekatan kuantitatif dengan jenis penelitian quasi-eksperimen. Subjek penelitian ini adalah kelas XI SMA Swasta di kecamatan Driyorejo - Gresik pada semester ganjil tahun akademik 2019/2020. Pengambilan sampel menggunakan purposive cluster sampling dengan mempertimbangkan karakteristik sekolah dan memperoleh dua sekolah, yaitu SMA Raden Fatah sebagai kelompok kontrol dan SMA AL-Furqon sebagai kelompok eksperimen. Jumlah siswa SMA Raden Fatah adalah 36 siswa sedangkan SMA AL-Furqon sebanyak 39 siswa. Dalam proses pembelajaran, kelompok kontrol menggunakan media presentasi powerpoint dan kelompok eksperimen memanfaatkan pembelajaran multimedia interaktif berbasis flash. Data penelitian dikumpulkan melalui tes identifikasi gaya belajar dan tes hasil belajar siswa. Data dianalisis dengan bantuan progam SPSS 24 for windows, dengan uji ANOVA dua arah pada tingkat signifikansi 0,05. Hasil penelitian ini yaitu terdapat pengaruh penggunaan multimedia pembelajaran interaktif antara kelompok siswa dengan gaya belajar visual, auditori dan kinestetik secara bersama-sama terhadap hasil belajar Bahasa Inggris siswa

How to Cite: Suryanto, S., Muhajir, M., \& Kusmiyati, K. (2021). Pengaruh Penggunaan Multimedia Interaktif dan Gaya Belajar Terhadap Hasil Belajar Bahasa Inggris. Jurnal Teknologi Pendidikan : Jurnal Penelitian dan Pengembangan Pembelajaran, 6(2), 160-167. doi:https://doi.org/10.33394/jtp.v6i2.3536

https://doi.org/10.33394/jtp.v6i2.3536

This is an open-access article under the CC-BY-SA License.

\section{Pendahuluan}

Hasil belajar Bahasa Inggris siswa pada kurikulum 2013 di Indonesia terbilang masih rendah. Pada jenjang sekolah menengah, guru masih menggunakan metode ceramah, dengan memanfaatkan papan tulis sebagai media pembelajaran. Selain itu, guru tidak pernah 
melakukan pengukuran keragaman gaya belajar siswa, sehingga proses pembelajaran tidak terakomodir dengan baik. Selain itu, penggunaan media pembelajaran yang tidak maksimal mengakibatkan keragaman gaya belajar siswa tidak terakomodir dengan maksimal, sehingga hasil belajar siswa menjadi tidak maksimal. Berdasarkan paparan tersebut, maka penyebab hasil belajar bahasa Inggris yang tidak maksimal yaitu (1) proses pembelajaran bahasa inggris belum memanfaatkan media pembelajaran secara maksimal, (2) keragaman gaya belajar siswa tidak pernah dilakukan oleh guru, dan (3) hasil belajar bahasa inggris siswa tidak maksimal (Cooez, 2006).

Media pembelajaran merupakan salah satu komponen yang sangat penting dalam proses peningkatan mutu pendidikan. Media yang tepat akan dapat membawa situasi belajar menjadi menyenangkan. Proses pembelajaran yang, menyenangkan, kreatif, tidak membosankan dan inovatif akan menjadi pilihan tepat bagi para guru untuk membelajarkan siswa. Cooze (2016:110) menyatakan, penggunaan teknologi informasi sebagai media pembelajaran akan berdampak baik terhadap peningkatan pengetahuan sisawa, karena siswa tidal dibebankan dengan model pembelajaran konvensional yang memaksa siswa untuk mendengarkan ceramah dan memcatat materi pembelajaran yang diberikan.

Kualitas pembelajaran masih belum mampu meningkatkan kebutuhan belajar dan hasil belajar siswa, karena kegiatan pembelajaran masih dilaksanakan dengan metode ceramah, dan mencatat tanpa memberikan pendampingan yang cukup terhadap siswa, sehingga tidak terjadi interaksi yang cukup terkait permasalahan yang dihadapi siswa selama proses pembelajaran berlangsung. Heinish, Molenda, Russell, \& Smaldino (2002) menyatakan bahwa, kegiatan pembelajaran yang berpusat pada siswa memungkinkan para guru dapat mengunakan waktu mereka untuk memeriksa dan memperbaiki masalah belajar siswa, atau berkonsultasi dengan siswa secara individual, sehingga pembelajaran tidak lagi bersumber pada guru. Dengan kata lain, media pembelajaran yang tepat akan dapat meningkatkan kualitas pembelajaran, serta dapat meningkatkan hasil belajar siswa. (Heinish, Molenda, Russell, 2002).

Perkembangan teknologi informasi hari ini menjadikan media pembelajaran bertransformasi menjadi sebuah media yang memiliki fitur lebih lengkap. Sebuah perangkat komputer dapat mengintegrasikan audio dan visual, akan tetapi dapat menyajikan rekaman suara, gambar dan video secara terpisah. Powerpoint, salah satu progam aplikasi yang banyak dimanfaatkan oleh guru, dapat juga menyajikan sebuah proses pembelajaran yang dapat menggabungkan suara, gambar, teks, dan vidio dalam sebuah progam presentasi, guna menjadikan sebuah proses pembelajaran yang efektif. Selain media presentasi powerpoint, media pembelajaran yang banyak dikembangkan adalah multimedia yang interaktif (MMI) berbasis flash yang menawarkan fitur lebih lengkap dibandingkan progam aplikasi powerpoint dan memungkinkan guru untuk dapat membuat media pembelajaran yang lebih efektif, serta dapat diintregasikan dengan aplikasi lainya baik secara offline dan online.

Kegiatan pembelajaran di SMA swasta Driyorejo GRESIK menunjukkan, sebagian besar proses pembelajaran masih menggunakan metode ceramah dan media papan tulis. Sebagian kecil guru saja yang memanfaatkan media presentasi powerpoint, sehingga pembelajaran menjadi kurang menarik. Pemanfaatan media interaktif masih belum menjadi pilihan para guru. Padatnya materi yang disampaikan tidak berimbang dengan waktu yang disediakan. Partisipasi aktif siswa tidak terlihat selam proses pembelajaran, sehingga komunikasi belajar sering sekali tidak berlangsung efektif dan efisien. Selain itu, kurang pengetahuan guru terhadap pemanfaatan teknologi informasi dalam proses pembelajaran, mengakibatkan tidak maksimalnya pengitegrasian TIK dalam proses pembelajaran. 
Strategi peningkatan kualitas pembelajaran melalui pendekatan pembelajaran berbasis TIK, salah satunya adalah dengan memanfaatkan multimedia interaktif. Multimedia pembelajaran interaktif dapat memberikan pengalaman belajar siswa menjadi lebih cepat dan menyenangkan. Rancangan pembelajaran dapat diatur secara sistematis serta menarik untuk mencapai kompetensi yang diharapkan, sesuai dengan materi ajar, batasan, dan bagaimana cara mengevaluasinya, sehingga implementasi dari penggunaan multimedia pembelajaran interaktif dapat menimbulkan perubahan atau pembaruan dalam tingkah laku dan kecakapan siswa.

Berdasarkan observasi dan wawancara dengan guru mata pelajaran Bahasa Inggris dan kepala SMA Al-Furqon, penyebab kesulitan belajar bahasa inggris siswa adalah pembelajaran yang cenderung berupa pemahaman materi yang bersifat abstrak. Kesulitan belajar siswa juga dipengaruhi oleh beberapa faktor, antara lain ; kurang konsentrasi saat belajar, siswa terlihat bicara sendiri saat pembelajaran berlangsung, ada siswa tidak serius mengikuti pembelajaran kemudian menggangu teman dibangkunya karena proses pembelajaran tidak dapat menarik perhatian siswa. Jika keadaan ini dibiarakan terus menerus akan menjadikan siswa bersangkutan ketinggalan pelajaran dan berdampak pada hasil belajarnya serta dapat mengganggu pencapaian belajar siswa lainya. Faktor-faktor yang mempengaruhi kesulitan belajar siswa, tentu berdampak kepada capaian hasil belajar siswa.

Keragaman karakter siswa adalah mutlak terjadi dalam satu rombongan belajar. Karana siswa mempunyai latar belakang yang berbeda satu dengan lainya, yang dapat mempengaruhi proses pembelajaran dan hasil belajar siswa. Dalam lingkup teknologi pembelajaran, sesuai definisi AECT 1994, karekteristik siswa merupakan salah satu domain desain pembelajaran. Seels dan Richey (1994) menyatakan, "leaner characteristics are those facets of the leaner's experiential background that impact the effectiveness of a learning process", artinya karakteristik siswa merupakan pengalaman latar belakang siswa yang dapat mempengaruhi keefektifan proses pembelajaran. Latar belakang siswa merupakan pengalaman yang dimiliki, termasuk didalamnya adalah pengetahuan dasar yang dimiliki, tingkat kecerdasan, emosi, motivasi keinginan belajar serta gaya belajarnya yang dapat mempengaruhi efektifitas belajarnya.(AECT, 1977) (Seels, B. B., \& Richey, 1994)

Salah satu karekteristik yang memiliki pengaruh signifikan adalah gaya belajar siswa. Gaya belajar adalah bagaimana siswa menyerap informasi yang diterima lalu cara siswa memproses informasi tersebut. Pada dasarnya siswa memiliki dan melibatkan tiga modalitas gaya belajar dalam menyarap informasi pada proses pembelajaran, yaitu; visiual, auditorial dan kinestetik. Namun, hanya satu dari tiga modalitas tersebut yang dominan terhadap siswa.

Gaya belajar siswa memiliki pengaruh yang signifikan dalam pemilihan media pembelajaran yang sesuai bagi siswa. Pada umunya, guru tidak pernah melakukan analisa belajar siswa, sehingga penerimaan siswa terhadap materi pelajaran menjadi tidak baik. Jika proses pembelajaran tidak dirasa tidak sesusi dengan gaya belajar siswa, maka kecenderungan siswa untuk tidak memperhatikan akan menjadi sangat tinggi, sehingga pesan pembelajaran yang akan disampaikan guru terhadap siswa cenderung menjadi tidak tepat sasaran.

Dari uraian masalah di atas dapat disimpulkan bahwa perlu adanya media yang dapat membantu meningkatkan hasil belajar siswa, serta dapat membantu guru dalam menyampaikan materi pembelajaran bahasa inggris terkait materi yang akan diajarkan pada semester berjalan. Peneliti memilih multimedia interaktif berbasis flash, karena progam aplikasi flash memungkinkan untuk dapat mengintegrasikan teks, gambar, suara, vidio dan animasi dalam sebuah progam multi media interaktif. Multimedia interaktif berbasis flash ini 
juga dilengkapi dengan soal latihan untuk evaluasi dan pembahasan, sehingga dapat digunakan secara mandiri oleh siswa. Multimedia interaktif berbasis flash juga dapat mengkomodir perbedaan gaya belajar siswa, sehingga proses pembelajaran yang maksimal akan menjadikan hasil belajar siswa dapat mengalami peningkatan.

\section{Metode Penelitian}

Penelitiam ini menggunakan pendekatan kuantitatif karena dianggap lebih mudah melakukan analisis data menggunakan angka sehingga lebih mudah diukur ketercapaian tujuan penelitian.Jenis penelitian yang digunakan dalam penelitian ini adalah quasi experimental Design dengan nonequivalent control group design.Populasi dari penelitian ini adalah siswa yang dijadikan obyek penelitian. Populasi penelitian ini adalah siswa-siswa Kelas VIII SMP Negeri 2 Tanjungbumi yang berjumlah 50 siswa yang terdiri dari 25 orang siswa kelas VIIIA dan 25 orang lagi kelas VIIIB. peneliti menggunakan lembar angket untuk pelaksanaan model cooperative learning Student Team Achievement Division (STAD), lembar observasi untuk aktivitas siswa, dan soal tes untuk mengumpulkan data hasil belajar siswa.

Data penelitian diperoleh oleh peneliti menggunakan instrumen penelitian yang telah melalui uji validitas dan reliabilitas. Data diperoleh dari dua aktivitas yang berbeda, dimana aktivitas pengumpulan data yang pertama dilakukan pada kelas ekperimen. Kelas eksperimen merupakan kelas yang menggunakan model pembelajaran kooperatif STAD dan kelas kontrol merupakan kelas yang tidak mendapat perlakuan atau menggunakan model pembelajaran konvensional. model pembelajaran konvensional yang dilakukan adalah ceramah dan pemberian tugas. Peneliti melakuan analisis data menggunakan rumus $t$-test. Pendekatan penelitian ini adalah pendekatan kuantitatif dengan jenis penelitian quasi experimental yang bertujuan untuk mencari keterkaitan hubugan antara suatu variabel tertentu, namun peneliti tidak memberikan kontrol penuh terhadap semua variabel yang didapatkan. Penelitian ini menggunakan rancangan quasi experiment yang paling sering dilakukan, terutama ketika tidak memungkinkan atau sulit menetapkan subjek secara random untuk pengelompokan. Hal ini disebabkan karena peneliti tidak dapat mengontrol pengaruh dari variabel lain diluar variabel yang diteliti, baik pengaruh internal maupun eksternal. Keraguan terhadp kesepadanan ini mengakibatkan desain ini disebut Randomized Control Group Prestest Postest Design. Penelitian ini akan dilaksanakan pada bulan Oktober-November 2019 di SMA AL-Furqon dan SMA Raden Fatah Driyorejo Gresik.

Populasi dalam penelitian ini seluruh siswa SMA AL-Furqon dan SMA Raden Fatah dari kelas XI. Pengambilan sampel dilakukan dengan teknik purposive sampling. Sampel dalam penelitian ini yaitu kelas XI SMA AL-Furqon yang berjumlah 39 siswa sebagai kelompok eksperimen dan kelas XI SMA Raden Fatah yang berjumlah 36 siswa sebagai kelompok kontrol. Instrumen penelitian yang digunakan dalam penelitian ini yaitu pre-test, treatmen, post-test dan penilaian untuk mengetahui hasil, perbedaan, dan adanya pengaruh multimedia pembelajaran interaktif serta angket untuk mengetahui gaya belajar siswa. Sebelum instrumen penelitian digunakan terlebih dahulu diuji dengan validasi tes dengan cara divalidkan kepada ahli untuk kemudian diujikan.

Uji yang digunakan penelitian ini adalah uji normalitas, uji homogenitas dan uji hipotesis. Uji normalitas dilakukan untuk menguji apakah data penelitian berdistribusi normal atau tidak. Uji homogenitas untuk menentukan sampel dari populasi dua kelompok yang homogen sedangkan uji hipotesis untuk mengetahui perbedaan hasil belajar bahasa inggris antara kelompok siswa yang memiliki gaya belajar visual, auditorial dan kinestetik. 
Begitupula untuk mengetahui adanya perbedaan hasil belajar bahasa inggris antara kelompok siswa diajar dengan menggunakan multimedia pembelajaran interaktif berbasis flash dan media presentasi powerpoint serta mengetahui adanya pengaruh penggunaan multimedia pemebalajaran interaktif dan gaya belajar siswa.

\section{Hasil Penelitian dan Pembahasan}

Dalam penelitian ini, sebelum menerapkan media pembelajaran, hasil prestest manujukkan nila rata-rata hasil belajar siswa pada kelompok kontrol adalah 54,6542 dan 56,8949 pada kelompok eksperimen. Hasil tersebut menunjukkan bahwa nilai rata-rata kelompok kontrol dan eksperimen berada dibawah nilai KKM yang telah ditetapkan yaitu 70. Hal ini menjukkan bahwa para siswa memiliki hasil belajar bahasa inggris yang kurang memuaskan. Setelah penerapan media pembelajaran, terdapat peningkatan hasil belajar siswa pada kelompok kontrol dan kelompok eksperimen. Nilai rata-rata kelompok kontrol adalah sebesar 74,6242 dan nilai rata-rata kelompok eksperimen adalah sebesar 73,3892. Nilai tersebut menunjukkan bahwa hasil belajar siswa pada masing-masing kelompok mengalami peningkatan disimpulkan bahwa penggunaan multimedia pembelajaran interaktif memberikan pengaruh positif terhadap hasil belajar siswa.

Hasil uji statistik pada penelitian ini menunjukkan bahwa terdapat perbedaan hasil belajar siswa secara signifikan melalui penerapan media pembelajaran. Seperti yang ditunjukkan dalam uji Anova yang menunjukka bahwa H0 dan dapat diterima. Dengan demikian dapat disimpulkan bahwa penerapan multimedia pembelajaran interaktif Bahasa Inggris dalam proses pembelajaran memberikan dampak yang signifikan terhadap hasil belajar Bahasa Inggris siswa. Temuan ini sejalan dengan penelitian yang dilakukan oleh Ilhan \& Oruc (Ilhan, G. O, 2016) yang menyimpulkan bahwa pengunaan multimedia memberikan peningkatan akademik siswa pada mata pelajaran ilmu sosial. Sejalan dengan itu Kusuma et al. (Kusuma, P. S., Chamisijatin, L., \& Widodo, 2015) menyimpulkan, bahwa pengunaan multimedia flash meningkatkan hasil belajar siswa dalam pembelajaran Ilmu Alam (Biologi). Selain meningkatkan hasil belajar siswa, Luaran et al. (Luaran, J. E., Muti, N. F. B. A., Nadzri, F. A., \& Rom, 2014) dalam hasil penelitian menyatakan, bahwa penggunaan multimedia dalam pembelajaran juga dapat mempermudah dan meningkatkan motivasi guru dalam meyampaikan pembelajaran.

Penelitian ini melibatkan 75 orang siswa sebagai sampel, terdiri atas 34 orang siswa dengan gaya belajar visual, 27 orang dengan gaya belajar auditori dan 14 siswa dengan gaya belajar kinestetik. Sampel penelitian ini dibagi menjadi dua kelompok yang diberikan perlakukan dengan memanfaatkan media pembelajaran berbeda, yaitu; 36 siswa dalam kelompok kontrol yang melakukan proses pembelajaran dengan media presentasi powerpoint dan 39 siswa dalam kelompok eksperimen dengan memanfaatkan multimedia pembelajaran interaktif Bahasa Inggris flash. Kelompok kontrol terdiri atas 16 siswa dengan gaya belajar visual, 12 siswa dengan gaya belajar auditori dan 8 siswa memiliki gaya belajar kinestetik, sedangkan kelompok eksperimen terdiri atas 18 siswa dengan gaya belajar visual, 15 siswa dengan gaya belajar auditori dan 6 siswa dengan gaya belajar kinestetik.

Dalam penelitian ini, hasil pretest berdasarkan gaya belajar siswa menunjukkan bahwa nilai rata-rata hasil belajar siswa pada kelompok kontrol dengan gaya belajar visual adalah 57,6006 dan 60,21 pada kelompok eksperimen. Hasil belajar siswa pada kelompok kontrol dengan gaya belajar auditori adalah 55,63 dan 54,5933 pada kelompok eksperimen. Hasil belajar siswa pada kelompok kontrol dengan gaya belajar kinestetik adalah 47,2975 dan 52,7033 pada kelompok eksperimen. Hasil tersebut menunjukkan bahwa nilai rata-rata 
kelompok kontrol dan eksperimen berada dibawah nilai KKM yang telah ditetapkan oleh guru mata pelajaran yaitu 70. Hal ini menujukkan bahwa para siswa memiliki hasil belajar yang kurang memuaskan. Setelah penerapan media, terdapat peningkatan hasil belajar siswa, baik pada kelompok kontrol dan kelompok eksperimen. Nilai rata-rata posttest kelompok kontrol dengan gaya belajar visual adalah 74,3244 dan 76,1267 pada kelompok eksperimen. Siswa pada kelompok kontrol dengan gaya belajar auditori adalah 74,7742 dan 72,974 pada kelompok eksperimen. Sedangkan siswa kelompok kontrol dengan gaya belajar kinestetik adalah 74,9988 dan 66,215 pada kelompok eksperimen. Nilai tersebut menunjukkan bahwa hasil belajar siswa pada kelompok eksperimen dengan gaya belajar visual, auditori dan kinestetik mengalami peningkatan pada hasil belajar.

Pada hasil uji statistik menunjukkan bahwa terdapat perbedaan hasil belajar bahasa inggris siswa secara signifikan berdasarkan perbedaan gaya belajar (visual, auditori, dan kinestetik). Seperti yang ditunjukkan dalam uji Anova bahwa H0 diterima dan Ha ditolak, artinya, hipotesis penelitian kedua teruji dan dapat diterima kebenaranya. Dengan demikian dapat disimpulkan bahwa terdapat perbedaan hasil belajar bahasa inggris siswa berdasarkan keragamaan gaya belajar (visual, auditori dan kinestetik).

Hasil tersebut menyimpulkan bahwa perbedaan gaya belajar siswa memberikan pengaruh terhadap hasil belajar bahasa inggris siswa. Keragaman gaya belajar siswa merupakan karakteristik siswa dalam memperoleh informasi melalui kecenderungan modalitas yang berbeda antar siswa yang mempengaruhi efektifitas proses pembelajarannya. Artinya, gaya belajar merupakan salah satu faktor karakteristik yang dapat menentukan hasil belajar siswa. Temuan ini sejalan dengan penelitian yang dilakukan oleh Surjono (Surjono, 2015) yang menyimpulkan bahwa penggunaan multimedia yang sesuai dengan karakteristik gaya belajar mahasiswa dapat memberikan hasil pembelajaran yang lebih baik dibandingkan dengan mahasiswa yang menggunakan multimedia tetapi tidak sesuai gaya belajarnya. Dengan kata lain, gaya belajar dapat mempengaruhi prestasi belajar siswa (Fan, K, and Xiao, 2015). Sejalan dengan itu, temuan Bhattacharyya \& Shariff (Bhattacharyya, E., \& Shariff, 2014) membuktikan, bahwa penyesuaian gaya belajar dalam berbagai pendekatan pembelajaran ternyata dapat meningkatkan potensi dan kemampuan belajar siswa.

Dalam penelitian ini, dengan uji Anova bahwa pengaruh antara penerapan multimedia pembelajaran interaktif dan gaya belajar terhadap hasil belajar siswa, diperoleh nilai signifikansi sebesar $0,009 \quad(0,009<0,05)$, nilai signifikansi ini lebih kecil dari 0,05. Berdasarkan perbandingan ini, maka dapat disimpulkan bahwa ada pengaruh antara penerapan multimedia pembelajaran interaktif dan gaya belajar siswa terhadap hasil belajarnya. Uji Anova menunjukkan bahwa H0 diterima dan Ha ditolak.

Hasil penelitian ini menunjukkan bahwa ada pengaruh antara penerapan multimedia pembalajaran interaktif dan gaya belajar terhadap hasil belajar siswa. Dengan adanya pengaruh tersebut menunjukkan bahwa kedua variabel tersebut secara bersama-sama mempengaruhi hasil belajar siswa. Kesimpulan ini juga dapat dilihat dari hasil uji hipotesis pertama dinyatakan ada pengaruh signifikansi dari keragaman gaya belajar siswa terhadap hasil belajar siswa dan hipotesis kedua menyatakan penerapan multimedia pembelajaran interaktif memberikan pengaruh positif terhadap hasil belajar siswa.

\section{Kesimpulan}

Berdasarkan hasil penelitian yang telah dilakukan di Sekolah Menengah Atas swasta kecamatan Driyorejo kabupaten Gresik pada semester ganjil tahun pelajaran 2019/2020, tentang pengaruh penggunaan multimedia pembelajaran interaktif dan gaya belajar terhadap 
hasil belajar siswa di Sekolah Menengah Atas swasta di kecamatan Driyorejo kabupaten Gresik, maka penulis menyajikan simpulan sebagai berikut;

1) Terdapat perbedaan hasil belajar Bahasa Inggris yang signifikan antara kelompok siswa yang diajar dengan menggunakan multimedia pembelajaran interaktif berbasis flash dan kelompok siswa yang diajar menggunakan media presentasi powerpoint. Perbedaan hasil belajar Bahasa Inggris terhadap kelompok siswa yang diajar dengan memanfaatkan multimedia pembelajaran interaktif berbasis flash dengan siswa yang diajar dengan menggunakan media presentasi powerpoint menunjukkan bahwa penggunaan multimedia pembelajaran interaktif dalam proses pembelajaran dapat meningkatkan hasil belajar siswa. Rerata skor hasil belajar yang memanfaatkan multimedia pembelajaran interaktif berbasis flash sebesar 73,3892, lebih kecil dari kelompok siswa yang diajar dengan memanfaatkan media presentasi powerpoint sebesar 74,6242.

2) Terdapat perbedaan hasil belajar Bahasa Inggris yang signifikan antara kelompok siswa yang memiliki gaya belajar visual. Auditori dan kinestetik. Perbedaan antara kelompok siswa dengan gaya belajar visual, auditori dan kinestetik baik pada kelompok eksperimen yang memanfaatkan multimedia pembelajaran interaktif berbasis flash maupun kelompok kontrol yang memanfaatkan media presentasi powerpoint dalam proses pembelajaran, secara signifikan menyebabkan perbedaan hasil belajar Bahasa Inggris siswa. Pada kelompok kontrol perolehan rata-rata hasil belajar Bahasa Inggris masing-masing gaya belajar adalah; kelompok siswa dengan gaya belajar visual sebesar 74,3244, kelompok siswa dengan gaya belajar auditori sebesar 74,7742 dan kelompok siswa dengan gaya belajar kinestetik sebesar 74,9988. Sedangkan pada kelompok eksperimen perolehan rerata pada hasil belajar Bahasa Inggris masing-masing kelompok gaya belajar adalah; kelompok siswa dengan gaya belajar visual sebesar 76,1267, kelompok siswa dengan gaya belajar auditori sebesar 72,974 dan kelompok siswa dengan gaya belajar kinestetik sebesar 66,215.

3) Terdapat pengaruh penggunaan multimedia pembelajaran interaktif antara kelompok siswa dengan gaya belajar visual, auditori dan kinestetik secara bersama-sama terhadap hasil belajar Bahasa Inggris siswa. Penggunaan multimedia pembelajaran interaktif antara kelompok siswa dengan gaya belajar visual, auditori dan kinestetik menunjukkan bahwa penggunaan multimedia pembelajaran interaktif dan gaya belajar secara bersama-sama mempengaruhi hasil belajar Bahasa Inggris siswa. Sehingga, dapat disimpulkan bahwa ada pengaruh penggunaan multimedia pembelajaran interaktif berbasis flash dan media presentasi powerpoint dan gaya belajar (visual, auditori dan kinestetik) terhadap hasil belajar Bahasa Inggris siswa.

\section{Saran}

Berdasarkan kesimpulan dari penelitian ini, maka terdapat beberapa saran antara lain; (1) Bagi guru Bahasa Inggris, disarankan untuk memanfaatkan multimedia pembelajaran interaktif dalam proses pembelajaran. Dengan memanfaatakan multimedia pembelajaran interaktif, minat belajar siswa menjadi meningkat dan pembelajaran dapat dilaksakan dengan lebih menyenangkan, sehingga hasil belajar siswa menjadi meningkat. (2) Bagi sekolah, disarankan berperan aktif dengan mengikutsertakan guru dalam berbagai pelatihan serta mengadakan studi banding di sekolah-sekolah yang lebih unggul guna untuk meningkatkan potensi dan kemampuan guru dalam mengelola proses pembelajaran sekolah sebaiknya secara berkala memberikan pelatihan pengembangan media pembelajaran berbasis teknologi informasi dalam bentuk multimedia pembelajaran interaktifatau multimedia lain yang sejenis, 
kepada guru. (3) Bagi peneliti selanjutnya, agar dapat melakukan penelitian dengan mengkolaborasikan multimedia pembelajaran interaktif dan model pembelajaran tertentu dengan mempertimbangkan gaya belajar siswa, selain visual, auditori, dan kinestetik (VAK).

\section{Daftar Pustaka}

AECT. (1977). The dufinition of education technology, AECT task force on definition and terminology. Washington D.C.: Association for Educational Communication and Technology.

Bhattacharyya, E., \& Shariff, A. B. M. S. (2014). Learning Style and its impact in higher education and human capital needs. Procedia - Social and Behavioral Sciences, 123, 485-494.

Cooez, A. C. (2006). 100 Ideas for Teaching English. London: Continum International Publishing Group.

Fan, K, and Xiao, P. (2015). The effects of learning styles and meaningfull learning on the learning achievement of gamification health education curriculum. URASIA Journal of Mathematics, Science, \& Technology Education, 11(5), 1112-1229. https://doi.org/https://doi.org/10.12973/eurasia.2015.1413a

Heinish, Molenda, Russell, \& S. (2002). Intructional technology and media for learning. (D. A Stollenwerk, H. D. Fraser, D. Parker, P. Burleson, M. Harla, \& R, L. Marcum, Eds.) (7th ed.). New Jersey.: Pearson Education, Ltd.

Ilhan, G. O, O. S. (2016). Effects of the use of multimedia on the students' performance, A case study of social studyes. Academic Journal Education Research and Reviews, 11(8), 877-882. https://doi.org/https://doi.org/10.5897/ERR2016.2741

Kemendiknas. (2007). Peraturan Menteri Pendidikan Nasional RI Nomor 41, Tahun 2007, tentang Standar Proses Pendidikan untuk Satuan Pendidikan Dasar dan Menengah. Jakarta: Kemendiknas.

Kusuma, P. S., Chamisijatin, L., \& Widodo, N. (2015). The influence of macromedia flash to students outcome on X science 4 Senior High School Pasuruan. In Seminar Nasional Pendidikan Biologi 2015 (pp. 386-394). Malang: Prodi Pendidikan Biologi FKIP Universitas Muhammadiyah Malang.

Luaran, J. E., Muti, N. F. B. A., Nadzri, F. A., \& Rom, K. B. B. M. (2014). Teaching with technology: Implications for preparatory progammers of science and mathematics educators. Procedia - Social and Behavioral Sciences, 123, 145-150.

Seels, B. B., \& Richey, R. C. (1994). Instructional techology: The definition and domains of the field. Washington D.C.: Association for Educational Communication and Technology.

Surjono, H. D. (2015). The effect of multimedia and learning style on student achievement in online electronics course. Turkish Online Journal of Educational Technology, 14(1), $116-123$. 